\title{
Understanding networks of actors involved in refugee access to higher education in Canada, England and France
}

\author{
A digital comparative approach
}

Melody Viczko, Marie-Agnès Détourbe and Shannon McKechnie

\begin{abstract}
In times of intense migrations, securing a brighter future through education has become a growing concern in many societies. In particular, access to higher education for refugees has been the object of multiple initiatives among governments, civil society and non-government organisations. However, only 3 per cent of refugees access higher education, and there is a need to better understand, support and develop successful access for refugees among policymakers, educators and researchers. This research takes an original comparative digital approach to identifying those networks in three countries: Canada, England and France. Our findings suggest that the nature of issues for refugee access to higher education is constructed differently in each national context, as the social relations between government, civil society, non-government agencies and higher education institutions are uniquely configured.
\end{abstract}

KEYWORDS

access to higher education, Canada, digital mapping, England, France, refugees

In the current context of intense forced migrations, refugee access to higher education is a growing concern among governments, civil society, and nongovernment organisations (NGOs). Over half of twenty-five million refugees globally are under the age of twenty-five, many of whom hold secondary or post-secondary education qualifications and have strong higher education aspirations (Dryden-Peterson 2011). Yet only 3 per cent actually access higher education (UNHCR 2019a; 2019b). Securing access to higher education for 
those who have both desire and academic ability remains problematic (Détourbe and Goastellec 2018; European Council on Refugees and Exiles 2016; Thompson 2014; UNESCO/Council of Europe 2017; UNHCR 2015). Further efforts are needed in nation states where education systems for post-secondary education are robust, including in Canada and the European Union (EU), where upwards of 40 per cent of the population have completed education beyond secondary schooling (EuroStats 2018; Statistics Canada 2017). Access to higher education is an issue of increasing importance to democratic societies, given that an educated citizenry is considered a major pillar of security in such societies (Council of Europe 2019). While there are data to support understanding of the rates of access and completion, as well as literature to inform the challenges that refugee students face, there is a dearth of mapping the policy contexts in which access to education for refugees plays out. The challenge among policymakers, educators and researchers is to understand, support and develop successful access to higher education for refugees.

In this article, we report on findings from a study aiming to understand the networks of actors involved in addressing refugee access to higher education in three countries: Canada, England and France. Our findings suggest that the nature of the issues for refugee access to higher education is taken up and constructed quite differently in each national context, as the social relations between government, civil society, non-government agencies and higher education institutions are uniquely configured. Consequently, the nature of the network shifts according to national context. The significance of this finding is twofold: to begin to understand the varied national engagements on the global issue of refugee access to higher education; and to explore how digital methods research can be used in comparative policy analysis research to demonstrate national agendas.

We begin with a brief review of the refugee access to higher education literature, followed by a contextual overview of the issue in each country under study. Then, after situating the theoretical perspectives of digital methods research and explaining the methods of our research, we elaborate on the network analysis in each national context in relation to our expert knowledge of refugee access within that region. We then discuss the findings on the issue networks from a comparative perspective, reflecting on the extent to which networks have emerged around the issue of refugee access to higher education across the three contexts. In the conclusion, we share 
recommendations for future research, with reflections about what this digital methods approach offers for comparative education.

\section{Refugee access to higher education}

Initiatives aimed at increasing refugee participation in higher education have multiplied over the last decade, particularly across Canada and the EU where a wealth of government-, higher education institution-, student-, NGO- and civil society-led programmes emerged, especially after the Syrian crisis (De Haene et al. 2018). The improvement to access is encouraging globally, as the number of refugee students who enter higher education has increased from 1 per cent to 3 per cent of the refugee population over the last two years. Yet, this access rate remains far below the global average rate for young people in the same age range (UNHCR 2019a). The UNHCR set a target of 15 per cent of refugee students accessing higher education by 2030 (UNHCR 2019a), including a call for global cooperation through the Global Compact on Refugees (UNHCR 2018a). Meeting the 15 per cent target is challenging, though. Because cross-country or cross-region mobility is at the heart of refugees' pathways, the issue of access to higher education spans across local higher education institution interest to national responsibility and global accountability, suggesting a tumultuous context for global cooperation. Research and policies are often unrelated, and there is a strong need for robust theoretical and methodological approaches to make sense of the issue at a global level. In this context, our article aims to shed light on the complex configuration of actors who take up and construct the issue of refugee access to higher education in three national contexts, whilst the original digital mapping methodology seeks to enhance the comparative approach of these various configurations. In the next sections, we place the issue of refugee access to higher education in the context of refugee policies in each jurisdiction.

\section{Canada}

In 2001, the Canadian federal government introduced the Immigration and Refugee Protection Act, which aims 'to permit Canada to pursue the maximum social, cultural and economic benefits of immigration' (Immigration and Refugee Protection Act 2001). This legislation marked a shift from the first formal immigration policy in Canada adopted in 1952, the 
Immigration Act, and the following pieces of legislation which supported its implementation in federal government practices (Garcia y Griego 1994). This shift marked the inclusion of refugees as a population for protection by federal government policies. At the national level, the federal government is responsible for immigration policies and regulations and, until recently, it has had no enormous problem of irregular refugee claimants compared to other democratic countries (Garcia y Griego 1994). In 2017, with shifting immigration and refugee policies out of the United States, there were increasing irregular claims made at various points between the Canadian and US border (Immigration and Refugee Board of Canada 2020), and questions were raised about the Canadian government's involvement in the Safe Third Country Agreement, in effect since 2004, in which the Canadian and US governments have declared reciprocal agreement that each country is safe for refugees, thereby closing the opportunity for refugee claimants at the Canada-US border. There have been serious critiques against this agreement in the wake of US federal policies criticised as being 'anti-refugee' and antiMuslim (Canadian Council for Refugees 2020).

Refugee access to higher education in Canada sits as an issue that straddles two governmental jurisdictions. The governance over refugees in Canada lies within the purview of the federal government department of Immigration, Refugees and Citizenship Canada. Protection for refugees and resettlement for newcomers to Canada is handled through this federal department. Yet, higher education is governed primarily through provincial government legislation, while there are certain collaborations and extensions between federal and provincial governments, especially related to international students and international education (Viczko 2020).

In 2015, the Canadian government announced an ambitious goal to be a leader on the global stage for international efforts to resettle Syrian refugees fleeing war and destitute conditions. The Canadian Minister of Immigration, Refugees and Citizenship (the then title of the current department of Immigration, Refugees and Citizenship Canada) revealed a plan to resettle twenty-five thousand Syrian refugees in November 2015 within less than six months. Dubbed the \#WelcomeRefugees initiative, several federal ministries initiated a five-phase plan to work with governments in Jordan, Lebanon and Turkey, along with international and Canadian partners (Government of Canada 2017). The plan was controversial, with concerns and doubts from opposition parties and settlement agencies alike, ranging from capacity challenges in dealing with the volume of refugees to outcries about security risks 
(CBC 2015). By 2017, just over forty thousand Syrian refugees have settled under this initiative (Government of Canada 2017).

Private sponsors, NGOs, and local governments at the provincial, territorial, and municipal levels played a significant role in the \#WelcomeRefugees initiative. Along this vein, colleges and universities across Canada announced commitments, many working with World University Service of Canada (WUSC), Universities Canada, Council of Ontario Universities and Colleges and Institutes Canada (CICan). The Canadian model for Syrian refugee settlement was praised by global institutions, including Filippo Grandi, the UN High Commissioner for Refugees (CBC 2016; UNHCR 2017), noting that Canada was among a small group of countries that allowed a private sponsor model, whereby costs and support for resettlement to be sponsored by private groups or individuals. This private model of sponsorship played an important role in the Canadian policy response, with two-thirds of refugees resettled in Canada being privately sponsored. In 2018, Canada admitted 28,100 refugees for resettlement, the largest intake of any country for that year (UNHCR 2019b), surpassing the United States. This notable intake was largely accomplished through the private sponsorship model.

The research about refugee pathways to Canadian higher education is developing. Recent literature indicates that about half of highly educated immigrants who relocated to Canada engaged in access to tertiary education (which includes all forms of education beyond secondary school) within four years of their arrival into the country (Adamuti-Trache 2013), yet immense challenges remain for most in their economic integration (Adamuti-Trache 2016; Wilkinson 2010). Furthermore, there is little research about refugee populations (Ferede 2012), even as some may be highly educated, and even less research about the policies in place to support tertiary education student refugees. The most recent data related to all forms of tertiary education indicate that refugees participate at lower rates than immigrants from Economic Class (with sufficient investment capital to immigrate without sponsorship), but at a comparable rate to those immigrants in the Family Class (family sponsorship) between 18 and 22 per cent (Propenko 2018) within the first seven years in Canada (though this data is dated in that it originates from refugees who landed between 2002 and 2005). Expectedly, the positive effects of participation in tertiary education on income are reported.

Given that many refugees experience challenges in attaining employment and return to government funding in the Canadian context (Ali et al. 2012; Jackson and Bauder 2014), many government programmes have been de- 
veloped to support Syrian refugees. However, a recent report released by a working group of the Canadian Senate (Standing Senate Committee on Human Rights 2016) indicates that Syrian refugees continue to face communication barriers, racism or harassment without feeling empowered to respond. Some refugees feel segregated; they hesitate to participate in activities in the community or their children's educational experiences. This leaves refugee students who do access higher education without cultural capital from familial engagements in their learning experiences due to the barriers family members reported.

\section{England}

Britain defined nationality and citizenship along universalist lines for Commonwealth nationals just after World War II: the aim of the British Nationality Act (1948) was to sustain relations with its former and current colonies and to grant broad rights to the new British citizens (Latour and Puzzo 2019). However, the subsequent immigration policies took a cautious approach to large-scale immigration for fear of overpopulation, unemployment and integration issues on racial and ethnic grounds.

The 'international migrant stock' in England increased from 5,926,200 to 8,543,100 between 2005 and 2017 (Détourbe 2018; UN Data 2018). Between 2014 and 2016, the United Kingdom recorded the second largest intake of non-European immigrants in the EU after Germany (European Commission/ EACEA/Eurydice 2019). This upward trend led to a tightening of immigration policies in the 2010s, as summarised in the 2010 Conservative Manifesto which stated that:

Immigration today is too high and needs to be reduced. We do not need to attract people to do jobs that could be carried out by British citizens, given the right training and support. So we will take steps to take net migration back to the levels of the 1990s - tens of thousands a year, not hundreds of thousands (Conservative Party 2010: 21).

One consequence was a significant drop in the number of 'refugees and others of concern to UNHCR': they were almost reduced by half between 2005 and 2017, from 316,600 to 151,700 (UNHCR 2018b). In 2017, the United Kingdom ranked fifth in the EU with 33,300 first-time asylum applications (European Commission/EACEA/Eurydice 2019). Another impact was the tightening of rules for international student recruitment as the government refused to leave 
international students out of the immigration net. Abuse and fraud in international students' recruitment at some institutions was publicly condemned as disguised immigration and led the Cameron-Clegg coalition government to take a series of restrictive measures. From April 2012, higher education institutions hosting international students, including private and foreign institutions, had to submit to inspections by the Quality Assurance Agency for Higher Education (QAA) in order to obtain the status of 'Highly Trusted Sponsor' which made it possible to issue a Confirmation of Acceptance for Studies to students. Under David Cameron's Conservative government in 2015, the status of Highly Trusted Sponsor was replaced by the 'Tier 4 Visa' whose delivery was conditioned both to QAA satisfactory inspection and to checks from UK Visa and Immigration (UKVI), under the direct authority of the Home Office. The Tier 4 Visa is issued for a period of four years and may be withdrawn by UKVI at any time should the strict requirements not be met.

In parallel with these inspections, the level of English required upon entry was raised, and student candidates were asked to provide evidence of sufficient financial resources (Universities UK 2013: 41). The tightening of measures also encompassed study visas: the study visa (Tier 4) was limited to a duration of five years, while the Tier 1 Post-Study Work Visa was considerably restricted. Lastly, 'credibility interviews' were introduced in July 2012 and extended to all new applicants in September 2013 in order to verify the authenticity of higher education projects (Universities UK 2014: 8).

Universities perceived these governmental measures as an infringement on their freedom to recruit and as a brake on their internationalisation strategies. The government's immigration policy was perceived as undermining the United Kingdom's reputation among international students, thus contributing to making the country less attractive. In a report on soft power and British influence in the world published in 2014, a House of Lords committee urged 'the Government to present and communicate their visa and immigration policies with a level of balance and in a tone that do not discourage those who would add to the UK's prosperity from coming to the UK and supporting its businesses and trade' (House of Lords 2014, §57).

In this context, opportunities of access to higher education for asylumseekers and refugees in England have become rather bleak, despite efforts by the Office for Fair Access (OFFA) to widen access internally to underrepresented groups in the domestic population. Depending on the asylum status they are granted (Refugee, Temporary Leave to Remain, Humanitarian Protection), tuition fees and welfare support vary (Détourbe 2018). Students 
in a refugee-like situation therefore mostly depend on higher education institutions' targeted programmes to enter higher education: local programmes like COMPASS at Birkbeck College, University of London, nationwide initiatives led by universities like the University of Sanctuary network or by charities like the Refugee Support Network provide various means of supporting refugee students and easing access. Such initiatives are crucial as 50 per cent of the first-time asylum applicants in the United Kingdom belong to the 18-34 age group (European Commission/EACEA/Eurydice 2019), even if asylum applications are gradually decreasing as a consequence of tighter immigration rules.

\section{France}

France has long prided itself on being a welcoming country. It has a tradition of defending human rights, as illustrated, for instance, by the creation of the League of Human Rights as early as 1898 after the Dreyfus case. The expression 'France, terre d'accueil' (France, welcome land) abounded in political discourse, especially after World War II when the country experienced labour shortages. From the 1970s, counter-discourses with more nationalistic overtones developed, following various economic and political crises, for example, in the wake of terrorist attacks on French ground. As in many other countries, French immigration policies have evolved with political, economic and social circumstances. In the mid-2010s, the Syrian crisis attracted important political attention in France. The need for solidarity was put forward and a new asylum law was enacted on 29 July 2015 to speed up and simplify asylum application procedures, as part of the European 'Asylum Pack' effort to deal with the refugee crisis. France took part in the European effort to welcome the new refugees $(158,200$ immigrants from non-EU countries were welcomed in France in 2016, the fifth largest intake in Europe) and the number of first-time applicants in 2017 was the third largest (European Commission/EACEA/Eurydice 2019). Recent figures show a sustained effort in granting asylum (more than 10 per cent between 2015 and 2019), ${ }^{1}$ an increase that is fairly proportional to the growth in asylum applications over the same period. The figures remain very low, however: in 2019, about one in four asylum applicants was granted asylum (36,512 in total), and the access rate to refugee status was 38.2 per cent.

Interestingly, the 18-34 age group which is the most likely to access higher education was found to be slightly higher in France than in other 
European countries (54.3 per cent, European Commission/EACEA/Eurydice 2019). Also, people in a refugee-like situation can access higher education in France whatever their status, and the preliminary authorisation usually required from international students (DAP) is waived for them. There is no formal policy approach to asylum-seekers and refugee access to higher education in France, as in the vast majority of EU countries (European Commission/EACEA/Eurydice 2019: 24). In this country characterised by strong central decision-making processes, a set of initiatives were taken at central level by various national higher education bodies, especially after the Syrian crisis. A network gathering higher education institutions and associations committed to integrating refugees into higher education was created in 2017, Migrants dans l'enseignement supérieur (MEnS, Migrants in Higher Education), under the aegis of Campus France, the French agency for the promotion of French higher education abroad. Interestingly, most programmes in France deliberately use the word 'migrant' when describing their actions as they consider that it is up to the Home Office (Ministère de l'intérieur) to define the administrative status of migrants, and that their own mission is to include migrants, whatever their status. The MEnS network consists of more than forty institutions and associations, and it is supported by the central body of university presidents and rectors (CPU, Conférence des présidents d'université): its actions range from scholarships to students, governmental funding for setting up academic bridging programmes, research programmes on migrations and actions led by the Francophone University Agency (Agence Universitaire de la Francophonie, AUF), as well as easier access to national social services for students. Other programmes like PAUSE target more specifically academics at risk and benefit from central funding as part of the MEnS programme ( $2 \mathrm{~m} €$ in 2019). A wealth of local initiatives by single higher education institutions have been taken as well, whether they are part of the MEnS or not: for example, the DILAMI programme in Toulouse offers linguistic, social and administrative support to migrants who want to start or proceed higher education studies; a specific bridging programme was opened at Université Panthéon Sorbonne to ease access to further higher education studies at this university while many other institutions like the University of Grenoble and Science Po Paris offer French language classes and nondegree bridging programmes including methodological help. Most of these programmes were initially student-led, then taken up at a more institutional level, a process which has been identified in many other European countries (e.g., ESU 2017). 
However, the lack of systematic monitoring of asylum-seekers and refugee access to higher education in France makes it difficult to know exactly how many of them are currently studying in French higher education. The only data is the number of refugee applications for recognition of qualifications which is an essential step in entering higher education - 1,757 in 2017 and 2,052 in 2018 (European Commission/EACEA/Eurydice 2019: 23). In parallel, very little research has been carried out to look into such initiatives. The few studies on the French case are part of broader comparative approaches in Europe (Goastellec 2018; Loo et al. 2018), with fewer studies still based on ethnographic approaches (Sontag 2019). Empirical studies researching migrant students' academic progress and social integration are lacking too.

\section{Theoretical approach}

Against the three country overviews we drew in the previous section, our aim in this research is to visualise and more fully understand the networks of actors assembling access to higher education for refugees as an issue in the three contexts and analyse the varying politicisation of the issue across the three networks through an innovative comparative approach in digital methods research. Aligning with issue-mapping research (Marres and Rogers 2008), we used issue network software to articulate the aim of issue mapping: 'Who's doing the issue (of refugee access to higher education), and what is the network around this issue?' (Marres and Rogers 2008; Rogers et al. 2015). Briefly stated, the project drew on innovative methodologies in digital research methods to map the networks of actors engaged in this issue, a social cartography of actors. The digital methods approach here involved a hyperlink analysis of organisations on the World Wide Web, essentially, social network analysis of digital space (Park and Thelwall 2003), using an open-source tool called the IssueCrawler from the Digital Methods Initiative at the University of Amsterdam. The purpose of this approach was to 'empirically map out a network of common meaning and purpose as represented through online linking practices' (Carpenter 2007: 648). A hyperlink from one website to another indicates 'membership in a common ideational community as well as acknowledgment of authority' (648) in an issue community. Through three social network graphs, we therefore make it possible to visualise the associations between actors working on the issue in each of the three countries based on frequency and broadness of connection in each national context. This methodology is particularly interesting in 
that it allows us to capture networks at a specific moment in time, thereby providing an initial snapshot of actors connected around the specific issue of refugee access to higher education.

This research builds on the Latourian approach of the social 'as the movement of actors constantly in the process of (re)assembling, (re)associating and (dis)agreeing' (Rogers et al. 2015: 15). Here, the focus is on the trails of connections of actors and issues that reassemble and reconnect around a social issue. In keeping with this dynamic approach of the social and drawing on the idea that governance happens in and by networks of actors/ agents, rather than merely through the government of a unitary state (Bevir and Rhodes 2003), the suggested approach in this project consists of issue mapping aimed at 'producing mappings that will aid in identifying and tracing the associations between actors involved in an issue' (Rogers et al. 2015: 9). Importantly, attention to the 'matters of concern' that mobilise actors and issues in networked ways, as Latour argues that focus must be given not to 'facts' but to ways in which concerns and issues drive the ways in which assemblages form (Latour 1987, 2005). Latour's approach is operationalised through the use of digital methods, using tools and approaches to data collection that 'repurpose' digitally native tools for social science research, in this instance, the study of hyperlinks.

The hyperlink, and the relations amongst hyperlinks, serve as the basis of our analysis. Link studies bring a focus to the hyperlink, or the URL, as playing a role in the way information is organised, displayed, and shared on the web. On the web, the hyperlink, or the URL, is the location of content and is also used within content in a number of ways. Links can indicate direction, moving a web user through content in a specific way, creating a directional path (DMI 2018). Of interest to us, links can indicate relations between sites and actors, as a type of citation (Carpenter et al. 2014) that represents membership of actors in an ideational community (as actors connected to issues), and as acknowledgement of authority (Carpenter 2007) as a citation denotes association. The assumption is that these actors are 'brought together by public entanglement with an affair, and thus potentially, with each other' (Sánchez-Querubín 2017: 96), whereby their relations in a larger network of refugee access to higher education in each national context can be made visible via their digital linking behaviours. The digital mapping approach, therefore, allows for a visualisation of associations which is otherwise challenging to capture on such a broad scale at a specific moment in time. 


\section{Issue mapping as methodology}

Our approach to collecting and analysing data to answer this question followed the 'data sprint' technique utilised by the Digital Methods Initiative at the University of Amsterdam (Berry et al. 2015; Munk et al. 2019). Data sprints involve a collective of researchers with varying experiences and expertise operationalising research questions, collecting data, and presenting preliminary results in a short period of time. Other research, analysis, or prototyping methods like the hackathon use similar restricted time frames, where the limitation of time encourages rapid progress and creativity (Berry et al. 2015). Our data sprint took place in July 2019 over a period of five days using 'search as research' and the IssueCrawler tool to map networks of actors in refugee access to higher education in Canada, France and England.

The first step in exploring issue networks on the web is to develop a list of 'well-chosen starting points' (Marres and Rogers 2008: 255) using multiple sites of knowledge, a method of triangulation. We drew first on our own expertise in this field through experience and through the literature to develop an initial list of key actors to include as starting points. Then, we expanded this list by utilising 'search as research' (Rogers 2013) as a method of actor discovery. In 'search as research' we used the functionality of Google to help us identify what other actors were doing work in the refugee access to higher education space. Keyword searches yielded some new actors, including higher education institutions that dedicated space on their website to the issue of refugee access. These institutions are included in the starting points for this network. ${ }^{2}$ The starting points list is 'well-chosen' in that the websites disclose activity around the issue of refugee access to higher education, indicating their commitment to the issue in the web space which can serve as a space of self-presentation (Marres and Rogers 2008).

We used the IssueCrawler to complete a hyperlink analysis for three countries: Canada, England, and France. The term hyperlink is used in this sense to denote an association between actors in which they may link unidirectionally (from one URL to another) or bidirectionally (two URLs linking to each other). The IssueCrawler approach differs from other network graphs in that it mainly allows for a global visualisation of the actors and whether they are related. Using hyperlink analysis, the IssueCrawler tool crawls the seed URLs that we input, identifying outlinks, and retains the pages that receive at least two links from the seeds. We repeated this process for three iterations, 
developing a network of relations between known and discovered actors active in the network through hyperlinking behaviours.

The IssueCrawler outputs visualisations of the network using the hyperlinks it traces. The visualisation includes nodes, which represent the names of actors whose websites were traced, and directional arrows, which represent how actor nodes link (e.g., node A links to node B, node B does not link to node A), a characteristic which enables us to visualise the relations as a network. In some cases, you will see arrows that are unidirectional indicating a connection from one node to another that was not reciprocal. Alternatively, there may be a bidirectional arrow which indicates that both nodes linked to each other. Theoretically, as previously described, the direction of the link indicates an acknowledgement, or citation, though not necessarily agreement with (Carpenter 2007). The size of each actor node visualised in the network is proportional to the number of inlinks it receives, noting its indegree count (http://www.govcom.org/Issuecrawler_instructions.htm). In other words, the larger the node, the more inlinks it received from other nodes in the visualisation, denoting its prominence of acknowledgement.

Then, once the network maps were visualised for each country within the IssueCrawler tool, we conducted a qualitative content analysis by examining the list of actors included in each country's network, visiting the websites of the actors, categorising the actors according to the nature of their work (e.g., university institution, NGO, government agency, etc.) based on the actors' own description of their website, triangulated with our own research knowledge about actors based on previous research. Additionally, we examined the direction of the links, considering possible trends (e.g., university institutions typically link outward). Finally, using these analyses, we qualitatively described the network in each country, as written in the following sections.

The literature shows that the Issue Crawler can effectively be used as a starting point in exploring actors and actor networks around specific issues (Carpenter 2011). In this context, the centrality of an actor, based on its indegree count, denotes 'how prominent an actor is in a network' (74), and those with many links from other nodes 'may possess social power, easily accessing resources and information from other nodes because of is central position' (Hafner-Burton et al. 2009: 19). The map allows us to visualise the relations between known actors and who they are connected to, so we are able to track and trace who is working on the issue of refugee access to higher education in particular national contexts. 


\section{IssueCrawler results}

\section{Canada}

The network for refugee access to higher education in Canada was completed on 2 May 2019 in Issue Crawler using the hyperlink analysis method. There were eleven nodes in the network map of linked actors in the Canadian context, with one main cluster and a few isolated actors. A single actor seems to organise a small group of other actors in an outward relationship, that is, the Canadian Council for Refugees points towards academic organisations (Social Science Research Network, Centre for Refugee Studies at York University), the Canadian government (canada.ca), international organisations such as Welcoming Refugees/Welcoming America (welcomingrefugee.org), the United Nations High Commissioner for Refugees (unhrc.org), and media (twitter.com).

Other organisations appear in the network as isolates (i.e., linked to by less than two other actors): Borderless Higher Education for Refugees (bher.org) at York University in Toronto that provides academic programmes

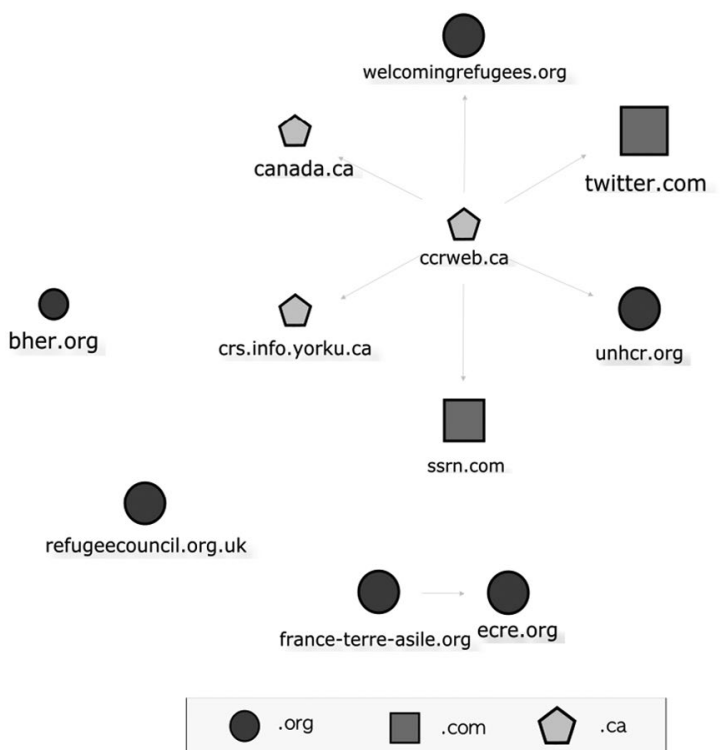

Figure 1. Canada network as rendered by IssueCrawler, using top nineteen results from known and search-as-research methods 
aimed at education for refugees where they need it, including training programmes in refugee camps; the Refugee Council (refugeecouncil.org.uk), an NGO that provides service to refugees in the United Kingdom, with specific focus on children and youth. An isolate node is one that does not meet the threshold for links, indicating either that it has a different network in which it works or that it is primarily a lone actor. A binodal link was included for the European Council on Refugees and Exiles (ecre.org) and France terre d'asile (france-terre-asile.org), a non-profit organisation aimed at ensuring the rights for asylum-seekers in France in alignment with European and international laws.

The network produced in the Canadian context is difficult to describe in that it is quite basic. The majority of the seed actors on the list, that is, actors perceived to be important in the issue of refugee access to higher education according to our professional expertise, did not appear on the network map, which indicates that they were not linked to each other at all when the data sprints were conducted. The simplicity of the network suggests a lack of coordination at the national level in this issue space. In the Canadian context, this may begin to relate to the federal-provincial boundaries of educational jurisdiction. Coordination around this issue may happen more robustly at the provincial-institutional level given that education is primarily a provincial government responsibility, which is not represented in this network. That is, what presents here as a lack of coordination requires a further probing for where coordination may happen. Our findings are not alone here, as policy coordination at the national level for international education has been elusive (see Sa and Sabzalieva 2018).

Additionally, in reviewing the literature, it appears that many policy responses within the Canadian context seem to have originated at the level of the university itself, being organically driven by local appeals to respond to refugee crises in the context of the Syrian refugee initiative \#WelcomeRefugees, with responses coming from student groups and concerned individuals in local institutions. Shared concern for response emerged through a national university-membership organisation, Universities Canada, which indicated the importance of WUSC in working with individual higher education institutions (Universities Canada 2015; WUSC 2016). In this way, it was surprising not to see more linking between WUSC and other actors, especially given its acknowledgement from the UNHCR as an organisation that delivered noteworthy programming for refugee access to higher education. We take this point up further in the comparative discussion that follows. 


\section{France}

The network for refugee access to higher education in France was completed on 22 April 2019 in Issue Crawler using the hyperlink analysis method. There were forty-eight nodes in the network map of linked actors in the French context, with some main clusters and no isolated actors. The dominant category of actors is governmental (ministries, agencies, etc.), with nine actors with the gouv.fr domains. There are several public service organisations linked to the government, such as public services in general (service-public.fr), more particularly social insurance and healthcare (Caisse d'allocations familiales caf.fr; Sécurité sociale securite-sociale.fr; ameli.fr), unemployment support (Pôle emploi pole-emploi.fr), welfare and support for the disabled (Maison départementale des personnes handicapées mdph.fr; agefiph.fr), and more. Research in universities is represented by both the

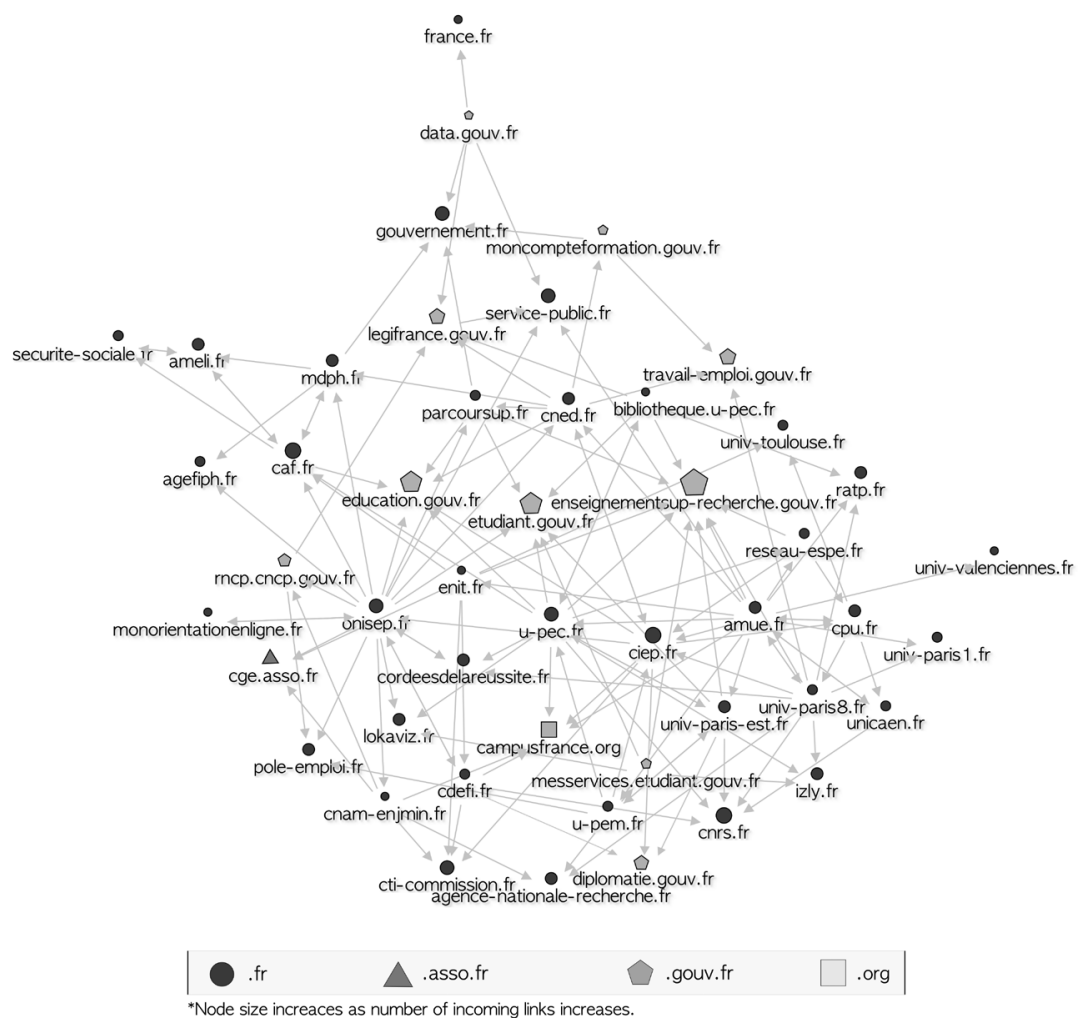

Figure 2. France network as rendered by IssueCrawler, using top nineteen results from known and search-as-research methods 
Agence-nationale-recherche.fr (National Research Agency), the only national funding body for research in France, and cnrs.fr (National Council for Scientific Research), the national research organisation. There are other organisations with smaller nodes which provide services to students, such as transport, tuition fees, navigating the university sector, careers, and so on.

Three nodes corresponded to ministries, two of which were the most significant nodes in the map: one was the French Ministry for Higher Education and Research (enseignementsup-recherche.gouv.fr); it received a total of 2,559 links from the crawled population; the second most significant node was the French Ministry of Education (education.gouv.fr) with 2,099 links. The third most significant node is the Ministry for Higher Education and Research's webpage dedicated to students (etudiant.gouv.fr).

Higher education as a field is represented by both higher education bodies and university institutions. For example, we see organisations like cpu.fr (Conférence des Présidents d'Université) and amue.fr (L’Agence de mutualisation des universités et établissements d'enseignement supérieur ou de recherche) and cge.asso.fr (Conférence des grandes écoles), which are central bodies representing French universities and grandes écoles nationally. Campus France is the agency responsible for promoting France as a site for study abroad and is closely linked to CIEP (recently renamed France Education internationale), the body in charge of providing international students with French language training and testing as well as recognition of academic qualifications, under the supervision of the Education Ministry.

The issue network shows a community composed of university institutions, higher education affiliated actors and government. Universities direct traffic to the public services.

One significant feature is that the actors are not specifically related to the refugee issue. The issue is dealt with centrally, mostly by governmental actors whose remit is higher education, student services and social welfare; existing support mechanisms have been extended to include refugees and recent networks like MEnS do not appear on the map as such, but through some of their individual members like the umbrella organisation CPU and a number of higher education institutions. Student-led organisations concerned with refugee issues do not appear on the map either as they are often locally based in specific higher education institutions which have integrated their actions into other activities. Similarly, immigration bodies (both NGOs and government bodies) do not appear on the map, which confirms the fact that immigration issues are dealt with separately in France by the Home Office 
and do not intersect with access to higher education issues as all migrant students can access higher education whatever their migratory status.

Overall, the French map illustrates the strong central authority of public bodies to which higher education actors relate when they deal with the issue of access to higher education. Higher education institutions are thus part of a dense network because they link out to central bodies, but they do not represent clusters themselves, nor are they linked to one another around this issue.

\section{England}

The network for refugee access to higher education in England was completed on 7 May 2019 in Issue Crawler using the hyperlink analysis method. There are thirty-seven nodes in the map mostly focused on clusters linking out from higher education institutions to government organisations involved with governing issues important to higher education students and to civil

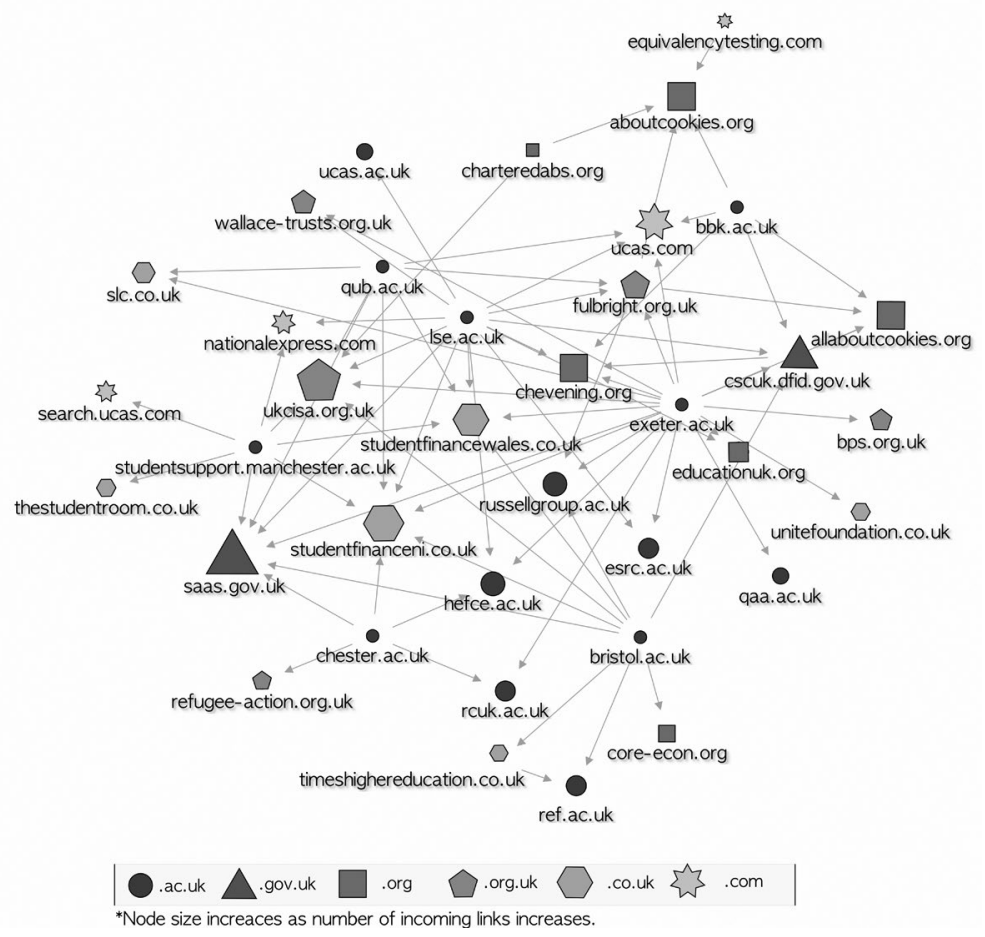

Figure 3. England network as rendered by IssueCrawler, using top nineteen results from known and search-as-research methods 
society organisations that advocate for access for students at large (whole student population beyond the concern of refugees per se). The biggest nodes are related to international students (ukcisa.org.uk, the UK Council for International Student Affairs is the national advisory body in charge of international students), and to student finance (studentfinanceni.co.uk; studentfinancewales.co.uk; saas.gov.uk). The size of the biggest nodes in this network do not contrast as much with the other nodes as they do in the French network for instance, suggesting a less centralised coordination.

The universities are mainly outward linking actors in the network in that they link to other organisations. The two university institutions with the highest number of links to the network are LSE and Exeter Universities. Other institutions included Bristol University, Birkbeck (University of London), Chester University, as well as membership organisations such as the Russell Group of twenty-four self-selected public university institutions and UKCISA (UK Council for International Student Affairs), a member organisation for universities and other educational institutions in the United Kingdom. The universities present in this network are sending organisations in that they link to other funding and service organisations, suggesting that university engagement in assembling the network is to provide important links to social services which provide access to services for which universities are not responsible.

Financial issues of access were visibly represented by actors in this network, including government agencies such as Chevening (chevening.org), a government agency for global scholarships; StudyUK, a British Council recruitment organisation for studying in the United Kingdom (educationuk.org), Higher Education Funding Council for England (hefce.co.uk ), now merged with OFFA to become the Office for Students, and various student financial aid agencies such as Student Finance Wales (studentfinancewales.co.uk), Student Finance Northern Ireland (studentfinanceni.co.uk), Student Awards Agency Scotland (saas.gov.uk), and The Student Room (thestudentroom. co.uk), as well as other non-profit government-owned organisations such as Student Loan Company (slc.co.uk). There were also private organisations that provide financial support to students such as Charles Wallace Trusts (wallace-trusts.org), a charity funding education in the United Kingdom for nationals from India, Pakistan, Bangladesh and Burma/Myanmar, the Fulbright Association (fulbright.org.uk) which provides opportunity for studying in the United States, Core (core-econ.org), and the Unite Foundation (unitefoundation.co.uk) which provides access to scholarships. 
Other government agencies are present here in this network. Research is represented through Economic and Social Research Council (esrc.org.uk), the Research Council UK (rcuk.ac.uk), and Research Excellence Framework (ref.ac.uk), which assesses research and, based on results, funding is granted to institutions. Universities and Colleges Admissions Service (ucas.ac.uk), an admissions portal for undergraduate and graduate education in the United Kingdom is also present with a number of inlinks.

Just as in France, institutional immigration bodies (e.g., the Home Office or UKVI) do not appear in the network, suggesting that higher education actors do not relate to them regarding immigrant access. Indeed, most immigrants fall into the 'international student' category when they enter higher education, so their immigrant status dissolves into an existing student status: the fact that, in many instances, the actors included in the network had pages within their websites dedicated specifically to refugees or asylum-seekers indicates that they have some specific concern about refugee condition, but it is mostly handled through existing, non-specific services and actors. The only specific refugee organisation on the map is a charity, Refugee Action (refugee-action.org.uk). Overall, the English map displays the prominence of student-finance bodies, both government-owned agencies or private foundations, revealing that tuition fees and higher education costs are a central concern.

\section{Reconsidering the issue of refugee access to higher education through digital methods research}

The network analysis undertaken in this study provided an innovative means to explore how the issue of refugee access to higher education was assembled in three different policy contexts with different geopolitical conditions. It helped visualise, in a measurable way, the quite distinctive nature and density of the issue networks in each national context, as well as the influential actors that assemble this issue at a specific moment in time.

An important finding is that in both England and France, the digital mapping approach did reveal multiple associations between a variety of actors around the issue of refugee access to higher education. In other words, the maps made it possible to capture the network of actors that emerged around this issue, thereby confirming its importance on the national political agenda in both contexts. Also, in England and France, the comparative approach revealed that refugee access to higher education was assembled 
mostly by existing higher education actors managing student access and services. However, the network displayed differences between both the centrality of some actors and the tightness of the network in the two contexts.

The French network was very dense and heavily influenced by the centrality of government actors: this feature is key for understanding the politicisation of refugee access to higher education as one that is mediated through several government ministries and offices. Refugee access to higher education as an issue was deeply embedded in other issues of social services, the French public higher education system being tightly coupled to a web of other public services centrally governed by ministries. The fact that actors and networks like MEnS (Migrants in Higher Education) or PAUSE, which were specifically created to tackle the issue of refugee access to higher education and appeared in our initial list, did not appear on the map suggests that they operate under the authority of central governmental bodies who are the central nodes and function as the main 'hubs of influence' (Carpenter 2011) in this context. At the time when the data sprints were conducted, these actors had thus not generated national coordination around the issue of refugee access, and central government ministries and offices appeared as the main hubs of influence in the network.

The English network comprised fewer nodes, revealing a less centralised higher education sector. The large share of inlinks to finance-related actors displayed the prominence of finance as an issue for refugees, in relation to their main administrative status as international students. ${ }^{3}$ This finding suggests that despite the introduction of fair access policies in the political landscape, as well as both nationwide and local initiatives around the issue of refugee access to higher education, finance stands as a central issue, and affordability is key to access for refugees and asylum-seekers. The varied type of financial actors, such as student aid organisations and scholarship/ bursary programmes, also showed the dispersed nature of this influence. Also notable was the absence, in the network, of national actors which are known to assemble around the issue of refugee access to higher education, like Cities and Universities of Sanctuary. In the English context, matters of finance therefore appeared to influence the space of refugee access, but the issue of refugee access itself did not appear as a powerful network-building force, revealing some level of marginality on the national agenda and/or a limited geographical scope of influence which the network analysis failed to capture.

The comparative approach revealed that the Canadian network was very different from the other two. It was very disparate and hardly coordinated 
at a national level, which could be explained by the fact that the Canadian higher education system is not coordinated through national actors in the same way that we may see explicit coordination of resources through other national governments. The very low number of nodes and the obvious lack of coordination in the digital space suggest that, even though refugee issues are predominantly governed by the federal ministries, they have not led so far to the emergence of a national network assembling the issue. The absence of WUSC on the map also provides interesting insights. This organisation is known to have strongly taken up the issue of refugee access to higher education in Canada, and their work is presented as central in the literature. It is also held up as an ideal organisation among policymakers and politicians in Canada. Its absence in the map does not suggest a diminished capacity for this organisation. However, it shows that WUSC has not emerged yet as an advocacy actor whose influence is able to set the issue as a central one on the national political agenda. We know that the universities themselves took up the call to act by sponsoring several individualised and local activities, but they have not clustered as a network around the issue. The invisibility of WUSC in the map also raises questions about the ways in which WUSC may be linked with other actors through a more dispersed network that has not yet been captured in our analysis.

A central finding about Canada, therefore, is that the issue of refugee access to higher education has failed so far to work as a network-building force overcoming an otherwise very loosely tied network of higher education actors at the national level. Our own engagement as researchers in this area provides some insight that the jurisdictional conditions of multiple educational systems in the federal system may contribute to challenges in how coordination is noted (Viczko 2020). A future query here could involve more explicit attention to provincial actors to see how they may serve as connecting political actors on this issue.

In all three contexts, then, the networks displayed the prominence of existing higher education or higher education-related actors assembling the issue of refugee access to higher education according to different national priorities and also the lack of emergence of powerful advocacy actors nationally. Also notable was the absence of transnational actors and international organisations in this space across the three contexts, with UNHCR and ECRE appearing only in one case in the otherwise very loose Canadian map. This is all the more interesting as just shortly before the data collection period, the UNHCR had launched its Global Compact on Refugees in which the 
quality and inclusiveness of national education systems' adoption of access for refugees to all levels of education, including tertiary education, was noted as an important aspect for the coordinated shared effort at addressing forced migration (UNHCR 2018a). Yet, international organisations remained invisible in the digital space that we explored. These analyses are helpful in beginning to think through the politics of association in how refugee access to higher education is dependent on national conditions and commitments.

Finally, though, we highlight the limitations of conducting this type of research. We acknowledge that 'not all links are equal' (Rogers 2012: 45) and, consequently, limitations of research should be considered. While each research method comes with limitations related to time and space, we acknowledge that this study is bound by the timeframe in which data were collected, knowing that associations change as new actors are enrolled, new initiatives and policies are engaged, and geopolitical conditions shift. Additionally, this analysis does not aim at understanding intentionality, that is, the rationale for why one actor links to another. In this analysis, we draw on theorising about digital methods that assumes activity in digital media spaces is a particular reality, worthy of its own analysis, a space in which realities about actor association take place (Rogers 2013). The assumption here is that this is one space in which association are formed, and increasingly so with the frequency by which digital media has become essential to organisational life (Marres 2017), but not the only space. Indeed, there may be other associations carried out in government meeting rooms, in policy documents, or in university institutions; other forms of research can bring representations of those networks to extend and refine knowledge about the issue.

Because there are limits to what one analysis might offer, further research must be conducted using different methods that examine other aspects about the politics of association of who works with whom on access to higher education for refugees as a policy issue, such as why transnational organisations were excluded from the data set. Also of consideration is an examination of both the strategy and intention behind membership in networks, which may be better known through more longitudinal ethnographic work. Different epistemological considerations bring about different understandings of this policy issue.

This research is an important contribution to understanding how refugee access to higher education is constructed in digital media spaces. Our findings suggest that the issue of refugee access to higher education has indeed 
led to the emergence of networks in England, France and, to a far lesser extent, Canada; the digital mapping methodology allowed us to understand: 'Who's doing "the issue of refugee access to higher education", and what is the network around this issue?'. It made it possible to identify which actors were involved in the issue and to trace the associations between them across the three contexts, thereby providing a useful basis for further research on this fast-evolving and central societal issue.

\section{Conclusion}

The digital methods approach we took in this research aimed to move beyond viewing the network of actors that are involved in refugee access as a metaphor for how organisations work. Rather, we aimed to show that the ordering of actor engagement, by examining where power for influencing refugee access lies, determined what kinds of political issue access became. Influence matters in setting which issues get taken up and how they circulate to privilege particular interests while keeping others on the margins. In this respect, our research showed that even though refugee access to higher education was taken up as an important issue in public discourse internationally, but also nationally in the French and Canadian contexts, and despite multiple programmes and initiatives in the three countries, it did not generate specific advocacy networks. Our findings showed that the issue was mostly assembled within existing structures of authority and governance: the actors known to engage in the issue nationally in each context and internationally did not appear as hubs of influence as specific issue networks did not assemble around them.

While each network represents the actors involved in assembling the refugee access to higher education at a specific moment in time, further attention can be given to: (1) how the networks evolve over time and which actors become influential; and (2) how sub-issues are taken up in each national context. These initial maps, therefore, provide a platform to further explore the particularity of the networks as well as the issues that actors privilege in each context. We see our research as a springboard for advocacy efforts within each context, and even transnationally, to more deeply be able to understand the nature of refugee access. All mapping is political (Robertson et al. 2012), and knowing how access is assembled across issues spaces is of interest for political actors of all kinds, not the least of which is refugee students themselves. 
Melody Viczko is Associate Professor in Critical Policy Studies in Education at Western University (Canada). Her research focuses on understanding how policy is enacted through multi-scalar governance practices, with an interest in international and comparative higher education policy. She is currently the President of the Comparative and International Education Society of Canada (CIESC).

Email: mviczko@uwo.ca (corresponding author)

Marie-Agnès Détourbe is Associate Professor in International Comparative Higher Education at INSA Toulouse, France. Her current research focuses on access to higher education for students with a forced migration background, from an international comparative perspective. Email: detourbe@insa-toulouse.fr

Shannon McKechnieis a PhD candidate in the Faculty of Education at Western University. Her current research explores the policy issue of student employability in Canadian higher education.

Email: smckech@uwo.ca

\section{Notes}

1. Ministère de l'Intérieur, Statistiques publiées en janvier 2021, https://www.immigration .interieur.gouv.fr/Info-ressources/Etudes-et-statistiques/Statistiques/Essentiel-de -l-immigration/Chiffres-cles

2. Starting point lists available from authors upon request.

3. The eligibility for home student status and the corresponding national fees and student grants are strictly controlled (Détourbe and Goastellec 2018b).

\section{References}

Adamuti-Trache, M. (2016), 'Pursuing post-secondary education in the host country and the occupational attainment of highly educated immigrants to Canada', Journal of Education and Work 29, no. 2: 143-166. https://doi.org/10.1080/13639080.2014.918942.

Adamuti-Trache, M., P. Anisef, R. Sweet and D. Walters (2013), 'Enriching foreign qualifications through Canadian post-secondary education: Who participates and why?', International Journal of Migration \& Integration 14, no. 1: 139-156. https://doi.org/ 10.1007/s12134-011-0228-y.

Ali, M. A., A. Kobayashi, S. Cliff-Jungling, J. Ochocka, J. Lomotey, L. Araujo and D. Kljujic (2012), Making Ontario Home: A Study of Settlement and Integration Services for Immigrants and Refugees (Toronto: Ontario Council of Agencies Serving Immigrants). 
Berry, D. M., E. Borra, A. Helmond, J-C. Plantin and J. W. Rettberg (2015), 'The data sprint approach: Exploring the field of digital humanities through Amazon's application programming interface', Digital Humanities Quarterly 9, no. 3, https://digitalsts.net/ wp-content/uploads/2019/11/30_digitalSTS_Data-Sprints.pdf.

Bevir, M. and R. A. W. Rhodes (2003), Interpreting British Governance (London, UK: Routledge).

British Nationality Act 1948, c. 56 (London: HMSO), https://www.legislation.gov.uk/ ukpga/1948/56/pdfs/ukpga_19480056_en.pdf.

Canadian Council for Refugees (2020), 'These moments define our humanity: We must remain open to refugees and vulnerable migrants', media release, 23 March, https:// ccrweb.ca/en/these-moments-define-our-humanity.

Carpenter, R. (2007), 'Studying issue (non)-adoption in transnational advocacy networks; International Organization 61, no. 3: 643-667. https://doi.org/10.1017/ S002081830707021X.

Carpenter, C. (2011), 'Vetting the advocacy agenda: Network centrality and the paradox of weapon norms', International Organizations, 65: 69-102. https://doi.org/ 10.10170S0020818310000329.

Carpenter, C., S. Duygulu, A. Montgomery and A. Rapp (2014), 'Explaining the advocacy agenda: Insights from the Human Security Network', International Organization 68, no. 2: 449-470. https://doi.org/ 10.1017/S0020818313000453.

CBC (Canadian Broadcasting Corporation) (2015), 'Justin Trudeau's promise to take 25,000 Syrian refugees this year "problematic", 28 October, http://www.cbc.ca/ news/politics/trudeau-syria-refugees-settlement-groups-1.3291959.

CBC (Canadian Broadcasting Corporation) (2016), 'Canada's refugee effort hailed as model for world by head of UN Agency', 21 March, https://www.cbc.ca/news/ politics/un-refugee-private-government-sponsor-1.3501400.

Conservative Party (2010), The 2010 Conservative Manifesto, 13 April, https://issuu.com/ conservatives/docs/cpmanifesto2010_hires/32.

Council of Europe (2019), Mapping for Council of Europe Education Activities on SDG 4.3 Equal access to technical/vocational and higher education. https://www.coe.int/ en/web/education/4.3-equal-access-to-technical/vocational-and-higher-education (accessed 11 August 2021).

De Haene, L., E. Neuman and G. Pataki (2018), 'Refugees in Europe: Educational policies and practices as spaces of hospitality?' European Educational Research Journal 17, no. 2: 211-218. https://doi.org/10.1177/1474904118762825.

Détourbe, M.-A (2018), 'Les universités britanniques et leur rapport au monde: les enjeux de l'internationalisation de la population étudiante [Internationalisation strategies at British universities]', Observatoire de la société britannique, 20: 37-66. https:// doi.org/10.4000/osb.1980.

Détourbe, M. A. and G. Goastellec (2018), 'Revisiting the issues of access to higher education and social stratification through the case of refugees: A comparative study of 
spaces of opportunity for refugee students in Germany and England', Social Science 17: 186-201.

DMI (Digital Methods Initiative) (2018), Lippmanian device, https://wiki.digitalmethods.net/ Dmi/ToolLippmannianDevice (accessed 20 September 2019).

Dryden-Peterson, S. (2011), Refugee Education: A Global Review (Geneva: UNHCR Policy Development and Evaluation Service).

European Commission/EACEA/Eurydice (2019), Integrating Asylum Seekers and Refugees into Higher Education in Europe: National Policies and Measures (Luxembourg: Publications Office of the European Union).

European Council on Refugees and Exiles (2016), 'Highlighting the need to prioritise access to higher education in humanitarian crises', https://www.ecre.org/ highlighting-the-need-to-prioritise-access-to-higher-education-in-humanitarian -crises/ (accessed 15 July 2018).

ESU (European Students' Union) (2017), Refugees welcome? Recognition of qualifications held by refugees and their access to higher education in Europe: Country analyses (Brussels: European Students' Union), https://www.esu-online.org/wp-content/ uploads/2017/05/ESU-Are-Refugees-Welcome_-WEBSITE-1.compressed-1.pdf (accessed 5 January 2020).

Eurostats (2018), Part de diplômés de l'enseignement supérieur parmi les 30-34 ans: l'UE tout proche de son objectif, http://www.cnos-scuola.it/sites/default/files/01_ Eurostat \%2025\%2004\%202018.pdf (accessed 15 July 2018).

Ferede, M. K. (2012), 'Structural factors associated with higher education access for firstgeneration refugees in Canada: An agenda for research', Refuge: Canada's Journal on Refugees 27, no. 2: 79-88. https://doi.org/10.25071/1920-7336.34724.

Garcia y Griego, M. (1994), 'Canada: Flexibility and control in immigration and refugee policy', in W. A Cornelius, P. L. Martin and J. E. Hollifield (eds), Controlling Immigration: A Global Perspective, 2nd ed. (Stanford, Calif.: Stanford University Press), 119-140.

Goastellec, G. (2018), 'Refugees' access to higher education in Europe: Comparative insights on a new public issue', in M.-A. Détourbe (ed), Inclusion through Access to Higher Education: Exploring the Dynamics between Access to Higher Education, Immigration and Languages (Rotterdam: Sense/Brill) (21-38).

Government of Canada (2017), '\#WelcomeRefugees: Canada resettles Syrian refugees', http://www.cic.gc.ca/english/refugees/welcome/milestones.asp (accessed 15 July 2018).

Hafner-Burton, E., M. Kahler and A. Montgomery (2009), 'Network analysis for International Relations', International Organization 63, no. 3: 559-592. https://doi.org/ $10.1017 /$ S0020818309090195.

House of Lords (2014), Select Committee on Soft Power and the UK's Influence: First Report. Persuasion and Power in the Modern World http://www.publications.parliament. uk/pa/ld201314/ldselect/ldsoftpower/150/15004.htm (accessed 23 January 2020). 
Immigration and Refugee Board of Canada (2020), 'Irregular border crosser statistics', https://irb-cisr.gc.ca/en/statistics/Pages/Irregular-border-crosser-statistics.aspx (accessed 25 May 2021).

Immigration and Refugee Protection Act, S.C. 2001, c.27. https://laws.justice.gc.ca/ PDF/I-2.5.pdf.

Jackson, S. and H. Bauder (2014), 'Neither temporary, nor permanent: The precarious employment experiences of refugee claimants in Canada', Journal of Refugee Studies 27, no. 3: 360-381.

Latour, B. (1987), 'The powers of association', in J. Law (ed.), Power, Action and Belief: A New Sociology of Knowledge? (London: Routledge), 264-280.

Latour, B. (2005), Reassembling the Social: An Introduction to Actor-Network Theory (London: Oxford University Press).

Latour, V. and C. Puzzo (2019), 'Framing and legitimising discriminatory immigration policies; A cross-channel survey (1948-1970)', in T. Harris (ed), Windrush (1948) and Rivers of Blood (1968): Legacy and assessment, (Routledge), 197-209. https:// doi.org/10.4324/9780429277771.

Loo, B., B. Streitwieser and J. Jeong (2018), 'Higher education's role in national refugee integration: Four cases', WENR: World Education News \& Reviews, 6 February, https://wenr.wes.org/2018/02/higher-educations-role-national-refugee-integration -four-cases (accessed 2 September 2021).

Marres, N. (2017) Digital Sociology (Cambridge, UK: Polity).

Marres, N. and R. Rogers (2008), 'Subsuming the ground: How local realities of the Fergana Valley, the Narmada Dams and the BTC pipeline are put to use on the web', Economy and Society 37, no. 2: 251-281. https://doi.org/10.1080/03085140801933314.DOI.

Munk, A., A. Meunier and T. Venturini (2019), 'Data sprints: A collaborative format in digital controversy mapping', in J. Vertesi, D. Ribes, C. DiSalvo, Y. Loukissas, L. Forlano, D. Rosner et al. (eds), DigitalSTS: A Field Guide for Science \& Technology Studies (Princeton University Press), 472-496, https://doi.org/10.2307/ j.ctvc77mp9.34.

Park, H. W. and M. Thelwall (2003), 'Hyperlink analyses of the World Wide Web: A review', Journal of Computer-Mediated Communication 8, no. 4. https://doi.org/ 10.1111/j.1083-6101.2003.tb00223.x.

Propenko, E. (2018), 'Refugees and Canadian post-secondary education: Characteristics and economic outcomes in comparison', (Statistics Canada Report No. 89-657-X2018001), https://www150.statcan.gc.ca/n1/en/pub/89-657-x/89-657 -x2018001-eng.pdf?st = LwSG-9e (accessed 3 January 2019).

Robertson, S., R. Dale, S. Moutsios, G. Nielsen, C. Shore and S. Wright (2012), Globalisation and Regionalisation in Higher Education: Toward a New Conceptual Framework (Aarhus: Aarhus University). https://edu.au.dk/fileadmin/www.dpu.dk/forskning/ forskningsprogrammer/epoke/workingpapers/WP_20_-_final.pdf (accessed 14 May 2013). 
Rogers, R. (2012), 'Mapping and the politics of web space', Theory, Culture \& Society 29, nos. 4-5. https://journals.sagepub.com/doi/pdf/10.1177/0263276412450926.

Rogers, R. (2013), Digital Methods (Boston: MIT Press).

Rogers, R., N. Sánchez-Querubín and A. Kil (2015), Issue Mapping for an Ageing Europe (Amsterdam: Amsterdam University Press), http://www.oapen.org/ search?identifier $=569806$.

Sa, C. and E. Sabzalieva (2018), 'The politics of the great brain race: Public policy and international student recruitment in Australia, Canada, England and the USA', Higher Education 75: 231-253. https://doi.org/10.1007/s10734-017-0133-1.

Sánchez-Querubín, N. (2017), 'Webs and streams: Mapping issue networks using hyperlinks, hashtags, and (potentially) embedded content', in M. T. Schäfer and K. van Es (eds), The Datafied Society: Studying Culture through Data (Amsterdam: Amsterdam University Press), 95-108.

Sontag, K. (2019), 'Refugee students' access to three European universities: An ethnographic study', Social Inclusion 7, no. 1: 71-79. https://doi.org/10.17645/si.v7.

Standing Senate Committee on Human Rights (2016), Finding Refuge in Canada: A Syrian Resettlement Story, https://sencanada.ca/content/sen/committee/421/RIDR/ Reports/RIDR_RPT_SyrianResettlement_FINAL_E.pdf (accessed 15 July 2018).

Statistics Canada (2017), Education in Canada: Key results from the Census 2016, https:// www150.statcan.gc.ca/n1/daily-quotidien/171129/dq171129a-eng.htm (accessed 15 July 2018).

Thompson, L. (2014), 'A world on the move: The benefits of migration', speech given in Brussels on behalf of the International Organization for Migration, 25 September, https: //www.iom.int/speeches-and-talks/world-move- benefits-migration (accessed 3 January 2019).

UN Data (2018), Country Profile. United Kingdom, http://data.un.org/en/iso/de.html (accessed 12 April 2018).

UNESCO/Council of Europe (2017), Recommendation on the Recognition of Refugees' Qualifications under the Lisbon Recognition Convention and Explanatory Memorandum, https://www.enic-naric.net/fileusers/1251_Recommendation_on_Recognition_of_ Qualifications_Held_by_Refugees_Displaced_Persons_and_Persons_in_a_Refugee_ like_Situation.pdf (accessed 12 March 2020).

UNHCR (United Nations High Commissioner for Refugees) (2015), Higher Education Considerations for Refugees in Countries affected by the Syria and Iraq Crises. (Geneva: UNHCR), http://www.unhcr.org/publications/education/568bc5279/educationbrief-7-higher- educationconsiderations-refugees-countries-affected.html (accessed on 11 September 2018).

UNHCR (United Nations High Commissioner for Refugees) (2017), 'UNHCR chief hails Canada as "champion” of refugees', https://www.unhcr.ca/news/unhcr-chief-hails -canada-as-champion-of-refugees/ (accessed 6 February 2019). 
UNHCR (United Nations High Commissioner for Refugees) (2018a), Global Compact on Refugees, https://www.unhcr.org/5c658aed4 (accessed 20 January 2019).

UNHCR (United Nations High Commissioner for Refugees) (2018b), Global Trends: Forced Displacement in 2017, https://www.unhcr.org/5b27be547.pdf (accessed 20 January 2019).

UNHCR (United Nations High Commissioner for Refugees) (2019a), Refugee Education 2030: A Strategy for Refugee Inclusion, https://www.unhcr.org/publications/ education/5d651da88d7/education-2030-strategy-refugee-education.html (accessed 20 September 2019).

UNHCR (United Nations High Commissioner for Refugees) (2019b), Global Trends: Forced Displacement in 2018, https://www.unhcr.org/5d08d7ee7.pdf (accessed 20 September 2019).

Universities Canada (2015), Canada's Universities Support Syrian Refugees, https:// www.univcan.ca/media-room/media-releases/canadas-universities-support-syrian -refugees (accessed 23 September 2019).

Universities UK (2013), The Funding Environment for Universities: An Assessment, http://www.universitiesuk.ac.uk/highereducation/Documents/2013/ FundingEnvironmentForUniversities.pdf (accessed 23 July 2020).

Universities UK (2014), International Students in Higher Education: the UK and its Competition, http://www.universitiesuk.ac.uk/highereducation/Documents/2014/ InternationalStudentsInHigherEducation.pdf (accessed 24 July 2020).

Viczko, M. (2020), 'Tracing controversies in internationalization: National actors in Canadian higher education', in M. Tamtik, R. Desai Trilokekar and G. A. Jones (eds), International Education as Public Policy in Canada (McGill-Queen's University Press), 313-335.

Wilkinson, L. (2010), 'Factors influencing the academic success of refugee youth in Canada', Journal of Youth Studies 4, no. 2: 173-193. https://doi.org/1080/13676260220134430.

WUSC (World University Service of Canada) (2016), The Canadian Post-Secondary Education Community's Response to the Refugee Crisis, https://wusc.ca/ the-canadian-post-secondary-education-communitys-response-to-the-refugee-crisis/ (accessed 11 August 2021). 